\title{
An overview of global layered intrusions, with a special focus on the Bushveld Complex, South Africa
}

\author{
W.D. Maier ${ }^{1 *}$, Qun-Ke Xia ${ }^{2}$ and W.D. Smith ${ }^{1}$ \\ ${ }^{1}$ Cardiff University, UK \\ ${ }^{2}$ Zhejiang University, Hangzhou, China \\ *Corresponding author e-mail: maierw@cardiff.ac.uk
}

\begin{abstract}
Summary Layered intrusions host some of the world's most important ore deposits, yet their global distribution, age, and petrogenesis remain poorly known. Here we provide an update on our current understanding and highlight some key outstanding research questions, notably on the potential importance of reactive flow. We present some preliminary data on water contents of Bushveld orthopyroxenes from which we calculated the water contents of the magma. The analysed Bushveld rocks, including the Merensky Reef, crystallised from relatively water-poor magma, similar to many other continental basalts.
\end{abstract}

\section{Introduction and background to current research}

Layered igneous intrusions have been identified in every continent on Earth (Fig. 1) and their existence has been hypothesised on the Moon and Mars. The greatest density of terrestrial intrusions occurs within stabilised Archaean cratons, particularly the Kaapvaal (e.g., Bushveld, Uitkomst, Stella, Molopo Farms, Trompsburg), Zimbabwe (e.g., Great Dyke), Pilbara (e.g., Munni Munni), Yilgarn (e.g., Windimurra, Jimberlana), Nain (e.g., Kiglapait, Fiskanaesset, Ilimaussaq), Superior (e.g., Duluth, Sudbury, Coldwell, Ring of Fire), Wyoming (Stillwater), Kola (e.g., Monchegorsk, Fedorova Tundra, Imandra) and Karelia (e.g., Kemi, Penikat, Portimo, Koillismaa) cratons. The dilated margins of cratonic blocks appear to be equally favourable, e.g., the Brasilia Belt of the Amazonia craton (hosting the Cana Brava, Niquelândia, and Barro Alto intrusions), the Halls Creek Orogen of the Kimberly craton (e.g., Hart, Savannah, Panton), the Kibaran Fold Belt of the Tanzania craton (e.g., Kabanga, Musongati, Kapalagulu), the Kotalahti Belt of the Karelia craton (e.g., Kotalahti, Rytky, Laukunkangas ), the Central Asian Orogenic Belt (e.g., Heishan, Huangshandong, Tulargen, Xiadong) and the Giles event of the Musgrave province, Australia (e.g., Wingellina Hills, Kalka, Mantamaru ). There are relatively few intrusions that show no obvious connection with Archaean cratons or their periphery, examples being the Chilas Complex of Pakistan and the Beja and Aguablanca intrusions of Portugal and Spain.

Layered intrusions occur throughout geological time, from the Archaean (including the $\sim 3123$ Ma Nuasahi intrusion, India and the 3033 Ma Stella intrusion, South Africa) to the Cenozoic (including the $\sim 55-45 \mathrm{Ma}$ east Greenland intrusions, e.g., Kruuse Fjord, Skaergaard, and Lilloise). There is no clear correlation between age and size; giant intrusions occur from the Archean, e.g., the $\sim 2.8$ Ga Windimurra intrusion, Australia, to the Phanerozoic, e.g., the $0.18 \mathrm{Ga}$ Dufek intrusion, Antarctica. Amongst the intrusions compiled in this study, $11.0 \%$ occur in the Archaean, $25.2 \%$ in the Proterozoic and $41.0 \%$ in the Phanerozoic (Fig. $2 ; 22.8 \%$ are unconstrained). The ages of layered intrusions correlate positively with the amalgamation of supercontinents, with numerous intrusions occurring at $\sim 2.5-2.4 \mathrm{Ga}$ (Kola and Karelia cratons, Great Dyke), 2.0-1.8 Ga (Kaapvaal and Superior cratons), 1.2-1.0 Ga (Midcontinent Rift), and 0.3-0.25 Ga (China and New Zealand). Intrusions temporally related to supercontinent dismemberment likely formed in response to mantle plume activity, whereas those occurring during intervals of supercontinent assembly have been explained either by (i) 
slab-rollback and consequent lithospheric extension, (ii) trans-tensional rift zones during oblique collision, or (iii) sub-continental lithospheric mantle (SCLM) delamination in response to enhanced subduction.

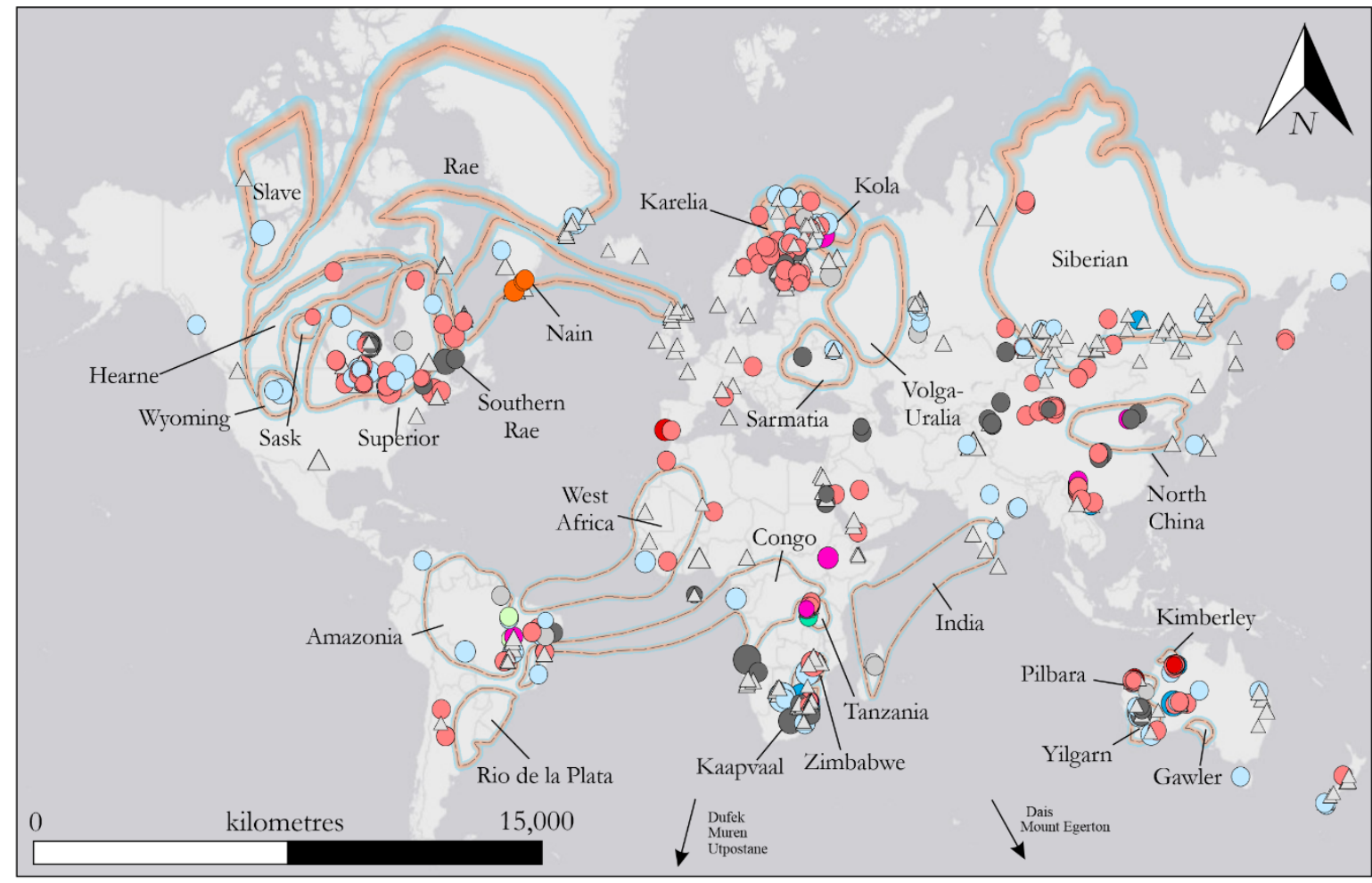

\begin{tabular}{|c|c|c|}
\hline \multicolumn{3}{|c|}{ Symbol classification $(n=610)$} \\
\hline No known occurrences & $\mathrm{Ni}-\mathrm{Cu}-(\mathrm{PGE})+\mathrm{Fe}-\mathrm{Ti}-\mathrm{V}$ & PGE- $(\mathrm{Cu})+$ Laterite \\
\hline Chromite & Ni Laterite & Phosphorous \\
\hline Fe-Ti-V & PGE-(Cu) & REE-Nb-Ta \\
\hline $\mathrm{Ni}-\mathrm{Cu}-(\mathrm{PGE})$ & PGE-(Cu) + Fe-Ti-V & \\
\hline
\end{tabular}

Figure 1: Distribution of global layered intrusions

\section{Research questions at hand}

Conventional models for the origin of layered intrusions (i.e. via tank-like chambers, Wager and Brown 1968) are increasingly challenged by new concepts including sill-like, out-ofsequence emplacement of melts or slurries (Bedard et al. 1988; Mungall et al. 2016), or recrystallisation of proto cumulates in response to percolation of volatiles and/or hydrous melt (Irvine 1980; McBirney 1987; Maier et al. 2021). Boudreau (2019) has gone as far as to suggest that large layered intrusions in general have undergone complete recrystallisation due to slow cooling and reactive flow of fluids. He went on to suggest that, in order to unravel the origin of the layering, the study of small intrusions that have experienced little recrsytallisation is more fruitful than that of large intrusions. The trouble is that the richest PGE reefs are hosted in the largest intrusions (Bushveld, Stillwater, Great Dyke), implying that when it comes to ore formation, size very much matters. Thus there remains a lot to be learned from studying the largest body of them all, ie the Bushveld.

Apart from the problem of unravelling the petrological complexities, another major problem is the sheer size of the Bushveld which prevented a systematic cataloguing and 
understanding of the range of compositional variations; In small intrusions, a single profile can be broadly representative of the compositional variation. In contrast, the $100000 \mathrm{~km} 2$ Bushveld Complex is underlain by a range of country rocks, basement structures, and lithospheric mantle types, and it has vastly different thickness and stratigraphic successions along its strike of 100s of $\mathrm{km}$. There is currently only 1 profile (based on drill cores and mine shaft samples) across the bulk of the complex (ie from the base to the top of the MZ). Detailed analysis of specific stratigraphic intervals along strike has only been done for the $\sim 50-200 \mathrm{~m}$ thick UG2-Merensky Reef interval (Maier and Eales 1997) and the 30-100 m Bastard Unit (De Klerk et al. 1992) and detailed along-strike comparison of a specific layer has only been done for PGE in the Merensky Reef (Naldrett et al. 2009).

\section{Future prospects}

In order to constrain the origin of the layering and the role of reactive flow, we will study a complete profile across the Bushveld Complex, and individual layers along, using FESEM element maps, micro X-ray maps, and water contents of pyroxenes (using EMP and FTIR). Reconnaissance data suggest relatively low water contents of the parent magmas (Fig. 2).

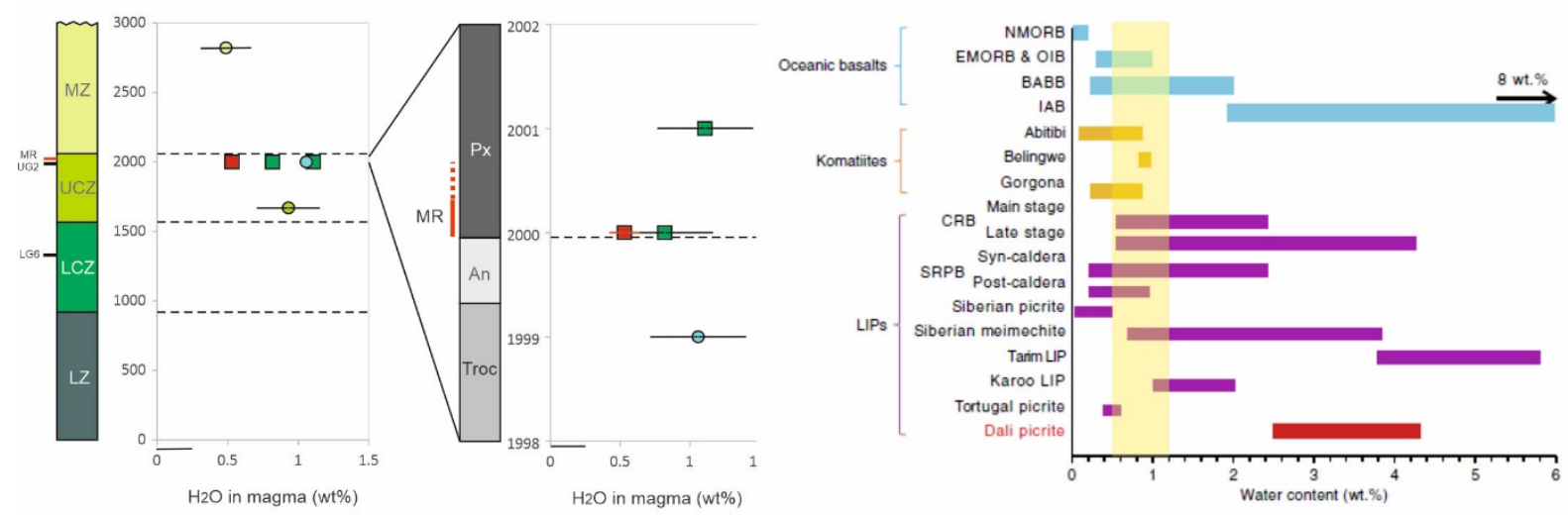

Figure 2. Calculated water contents of melts parental to Bushveld cumulates, based on water contents in orthopyroxene. LIP data from Liu et al. (2017).

\section{References:}

Bohrson WA, Spera FJ, Ghiorso MS, Brown G.A, Creamer JB, Mayfield A (2014) Thermodynamic model for energy-constrained open-system evolution of crustal magma bodies undergoing simultaneous recharge, assimilation and crystallization: the Magma Chamber Simulator. J Petrol 55:1685-1717.

Bédard JH, Sparks RSJ, Renner R, et al (1988) Peridotite sills and metasomatic gabbros in the Eastern Layered Series of the Rhum complex. J Geol Soc London 145:207-224Bruce PM, Huppert HE (1990) Solidification and melting along dykes by the laminar flow of basaltic magma. In: Ryan MP (ed) Magma transport and storage. Wiley, New York, pp 87-101.

Boudreau AE (2019) Hydromagmatic processes and platinum-group element deposits in layered intrusions. Cambridge University Press

De Klerk WJ (1992) Petrogenesis of the upper critical zone of the Western Bushveld complex with emphasis on the UG1 footwall and Bastard Units. Ph.D. thesis, Rhodes University, Grahamstown

Irvine NT (1980) Magmatic infiltration metasomatism, double diffusive fractional crystallization, and adcumulus growth in the Muskox intrusion and other layered intrusions. Phys Magmat Process

Liu J, Xia QK, Kuritani T, Hanski E and Yu HR (2017) Mantle hydration and the role of water in the generation of large igneous provinces. Nature communications, 8, pp.1-8.

Maier WD, Eales HV (1997) Correlation within the UG2-Merensky Reef interval of the Western Bushveld Complex, based on geochemical, mineralogical and petrological data. Geological Survey of South Africa Bulletin, vol 120 
Maier WD, Barnes S-J, Muir D, et al (2021) Formation of Bushveld anorthosite by reactive porous flow. Contrib to Mineral Petrol 176:1-12

Mungall JE, Kamo SL, McQuade S (2016) U-Pb geochronology documents out-of-sequence emplacement of ultramafic layers in the Bushveld Igneous Complex of South Africa. Nat Commun 7:1-13

Naldrett AJ, Wilson A, Kinnaird J, Chunnett G (2009) PGE tenor and metal ratios within and below the Merensky Reef, Bushveld Complex: implications for its genesis. J Petrol 50:625-659

Wager LR, Brown GM (1968) Layered igneous intrusions. Edinburgh London Oliver Boyd 1-588 